\title{
Mutual conditioning of factors of regional economic integration in Europe
}

\section{Међусобна условљеност фактора регионалне економске интеграције у Европи}

\author{
Miloš Srzentić ${ }^{*}$ \\ Doctor of Economic Sciences, Megatrend University, Republic of Serbia srzenticmil@sezampro.rs
}

\begin{abstract}
This paper looks into one of the basic theoretical concepts of mutual cooperation of regions in Europe, known as the concept of Europe of the Regions. Through it could be observed the influence of non-economic as well as economic factors participating in creating regional economic integration. According to this concept, multiple regions join as members into one region for easier and faster realization of some common functions determined in advance. By itself, during the joining of those regions, impact of available factors of integration in observed regions is directed primarily toward the successful realization of the target function. The concept of Europe of the Regions is analysed in this paper predominantly on examples of joining of multiple border regions from two or more different states into one cross-border region. The results of the research conducted in this paper are presented in its final section, where the attention is particularly focused on current problems creators of macroeconomic policies are faced with in their attempts to establish firmer and more comprehensive connections among border regions.
\end{abstract}

Keywords: regional economic integration, integration factors

JEL classification: F00, F15

Сажетак: У овом раду је разматран један од основних теоријских концепата међусобне сарадње региона у Европи, који се назива концептом Европе региона. Преко њега се може посматрати деловање како неекономских, тако и економских, фактора који учествују у формирању регионалне економске интеграције. Према овом концепту, више региона се удружује у један регион у циљу лакшег и бржег остваривања неке унапред одређене заједничке функције. Самим тиме, приликом удруживања тих региона, деловање разположивих фактора интеграције у њима је усмерено превасходно ка успешној реализацији те циљне фуннције. Концепт Европе региона је у овом раду најчешће анализиран на примерима удруживања по неколико пограничних региона из две или више различитих држава у један прекогранични регион. Резултати истраживања које је спроведено у овом раду су презентовани у његовом последњем делу, где је посебно скренута пажња на актуелне проблеме са којима се суочавају креатори макроекономске политике приликом покушаја да успоставе чвршћу и свеобухватнију повезаност пограничних региона.

Кључне речи: регионална економска интеграција, фактори интеграције

JEЛ класификација: F00, F15

\section{Introduction}

The basic problem considered in this paper relates to the fact that many attempts of mutual cooperation of border regions do not produce positive results in adequate measure. For this

Corresponding author 
reason, an analysis was conducted of factors of regional economic integration the acting of which determines the form and content of that cooperation. Examination of the sequence and the extent of implementation of those factors makes the content of the object of research of this paper. The aim of the paper was to determine whether and in which way the observed factors of regional economic integration are mutually conditioned. Mutual comparison of factors of integration by the method of comparative analysis is conducted at the beginning. In the next section of the paper, economic and non-economic factors of integration are considered in the following part of the paper with methods of quantitative and qualitative analysis, The basic hypothesis examined in this paper is presented in the form: the stronger the positive influence of non-economic factors of integration that economic factors, the better they will contribute to the creation of mutual cooperation of border regions.

The theoretical concept of mutual cooperation of two or more regions observed in this paper is called the concept of Europe of the Regions. Its special feeature consists in the fact that it implies creation of one larger region out of several smaller regions in accordance with functional principles. Consequently, for one bigger region to be formed, two or more smaller regions need to be grouped in order to perform some of the state or social functions faster and with better quality.

This paper particularly analyses cross-border cooperation, above all within the EU, between border regions belonging to member countries of EU. Those are regions which are usually, in administrative sense, still located on the existing borders of national states, which are at the same time also members of EU. The final section of this paper also analyses cross-border cooperation between border regions within member countries of EU establishing relations with countries which are not members of EU, but in most cases, are candidate countries for entering its membership. Realization of such cooperation is implemented in practice in such a way that financial means are separated on the communitarian level for certain time periods. They serve for conducting appropriate programs in order to harmonize regulations and incentives of common activities between such border regions.

Examples of border regions observed here show both positive and negative effects of their cooperation, during potential accession to unique cross-border regions. The analysis of existing forms of that cooperation is conditioned by the action of the considered factors. In final section of the paper, this analysis is performed in such a way that the influence of one of dominant observed factors of integration is compared with the influences of other factors of integration.

The obtained results are grouped based on the content of the object of that analysis in each of three basic parts of the paper. The first part of the paper contains analysis of noneconomic factors of integration. Economic factors of integration are considered in the second part of the paper. A potential mutual dependency of these two groups of factors is observed in the last part of the paper. 


\section{Definition of basic theoretical notions}

Influences of economic and non-economic factors of integration were examined on examples of forming of cross-border regions in Europe. They can be defined as territorial entities comprised of several local or regional administrative units whose headquarters are situated in different states and have resolving of common problems as a goal (Russo, 2012, p. 11).

European cross-border cooperation is most often specifically conducted through INTERREG programmes, whereby it comes to cooperation between NUTS3 regions, from at least two different member states of EU, which are situated either on common border of those states or in its immediate geographical proximity (Medeiros, 2019, p. 5). In that way Member States of the EU consciously finance certain forms and levels of autonomy of their border areas with the aim to create unique cross-border regions which have elements of supranational character (Knippenberg, 2004, p. 622).

The creation of Euroregions came as a result of a particular form of cooperation of border regions. These forms of regional connecting imply that mutual cooperation of border regions is established on common institutional bases, through which common priorities and ways of their realization are defined. It is in the concept of Europe of the regions that Forming of Euroregions finds its theoretical basis However, unlike that concept, what is continuously present here is simultaneous influence of several factors of integration (Wroblewski \& Kasperek, 2019, p. 6), which will be discussed in the final section part of this paper.

Non-economic factors that affect forming regional integrations include geographic, demographic and political factors. The group of geographic factors refers to natural corridors which spatially connect two or more border regions. Demographic factors can be defined as number and structure of population in border regions featuring as the base of their mutual integration. Political factors include forms of political activity directed on territorial and administrative connecting of border regions.

Economic factors refer to static and dynamic trade effects. When trade in a newly created integration takes place in existing economic structure, these are regarded as static effects. Dynamic effects are long-term effects changing economic structure. In a newly created integration, they lead to acceleration of medium- and long-term economic growth. These effects comprise: specialization in production, better allocation of resources, usage of economies of scale and increase in productivity by implementation of new technologies and investments (Marinov, 2015, p. 29). Effect which is particularly noticeable is specialization in production, which implies permanent orientation to development of only particular types of products on the territory of the entire country or of one of its regions (Timmer et al, 2019, p. 4). 


\section{Non-economic factors}

\subsection{Geographic factors}

Depending on topological characteristics of the terrain comprising border regions, geographical factors connecting them could be divided into land and water. The navigable corridor Rhine-Main-Danube could be specified as the most obvious example of it. The border regions described below, through which this navigation corridor passes, are selected for the needs of this analysis.

Border region of Gelderland in the Netherlands, with the biggest city of Arnhem, is a notable example, stretching up to urban agglomeration encompassing Rotterdam, one of the world's biggest harbours. Dusseldorf and Cologne, border regions in Germany with eponymous cities, follow as adjacent sections. Parts of these regions constitute Euroregion Rhine Waal. Through INTERREG program, at the beginning of the 90-ties of XX century, most of the funds allocated for financing this cross-border region was spent for transport, infrastructure and tourism. These economic factors were directly conditioned by geographic factors. Total amount allocated for Netherlands-Germany cross-border cooperation through INTERREG program for the period from 2014 to 2020 amounted to around 440 million euros (Euregio, 2020).

On the opposite end of that navigation corridor are border regions in Romania with harbour Constanţa and border regions in Bulgaria with harbour Varna. Both these harbours, Constanţa in Romania and Varna in Bulgaria, are situated on the Black Sea. The biggest part of transport of people and goods, which is carried out through them toward the rest of the European continent, continues down the river Danube. Through INTERREG program for this cross-border cooperation of Romania and Bulgaria, as a part of the Danube strategy to a significant extent, around 260 million euros were allocated for the same observed period from 2014 to 2020 (Filip \& Bogdan, 2016, p. 32). The largest part, around 85\%, of projects included in this part of INTERREG program are financed through European Fund for Regional Development. The program area comprises 15 administrative units, each of which features as one region according to NUTS3 classification. Seven of these entities are located in Romania and eight in Bulgaria. As member states of EU, Romania and Bulgaria participate in their financing with total of 13\% (Ministry of Public Development and Public Works, 2020).

It can be seen from these observed examples that, in this case, it is the geographic interconnection of observed regions that features as the basic determinant, which decisively influences potential forming of regional economic integration. Accordingly, it can be stated that geographic factor is the dominant factor of integrations observed and discussed in this paper.

\subsection{Demographic factors}

Ethnicity of population in different border regions features as the basis of most of political factors Observed from the other side, structure of population, which precisely implies 
similar ethnicity, features as the primary demographic factor placed in the basis of each cross-border integration of two or more border regions. Similar educational structure, which makes the basis for geographic and professional mobility of labour force, is also one of basic demographic factors enabling stronger connections between border regions. Influences of demographic factors can also be expressed through differences and similarities in the usage of officially recognized languages in a particular speaking area, well as belonging to a certain religious community.

Cooperation of the Walloon part of Belgium with France and Flemish part of Belgium with the Netherlands represents an example of influences of demographic factors on integrative processes in Europe considered herein. Around $40 \%$ of total population of Belgium live in the French-speaking Walloon part of the country. According to NUTS3 qualification, almost half of the total number of regions in Wallonia are situated on the border with France, thus achieving preconditions for establishment of mutual cooperation and forming cross-border regions. Education in Wallonia is compulsory from the age of six to eighteen, whereas in France that time span is officially from the age of six to sixteen. In the last few years both in Wallonia and in France more than $45 \%$ of young people aged from 25 to 34 attend some form of high education (OECD, 2014). The predominant religion in Walloon is, like in France, Roman Catholic denomination. The Dutch-speaking Flemish part of Belgium is home to $59 \%$ of total population. Also according to NUTS3 classification, more than a third of total number of regions in Flanders are situated along the border with the Netherlands. Unlike Flanders, where education is compulsory up to the age of 18 , in the Netherlands it is compulsory up to the age of 16 , with also very high percentage of highly educated population, particularly of younger generations. The highest number of the Flemings, like of the Dutch, belong to Roman Catholic denomination. After comparative analysis it can be stated that, both observed similarities and complementary characteristics of the observed regions represent precisely the demographic factors of their integration.

On the other hand, when these two regions are observed as parts of Euroregion, the following can also be noticed. As early as the early 1990s, when the Euroregion encompassing Belgium was formed, beside Wallonia and Flanders, it also comprised Brussels, while in France it included region of Nord-Pas-de-Calais and region of Kent in England. However, in this Euroregion, economic and political factors still have stronger influence on its functioning over demographic factors. In that period, however, the movement of people between regions comprising this Euroregion caused by demographic factors was minimal. The following years saw a significant increase in the movement of people between these regions. This happened only because of an inflow of foreign and domestic investments, often from these regions and because of political cooperation and decisions preceding their inflow. By that, this increase in the movement of people represents labour force mobility caused by economic and political factors. Until the beginning of the year 2000, as a consequence of that, 241 British companies were located only in the Nord-Pas-de Calais region, employing 26,000 people. Compared with that, in the same part of the observed Euroregion during that period, 237 Belgian companies were located, employing 16,000 people (Collier \& Vickerman, 2002, p. 11). 
The reason for such unequal influence of observed factors can be sought in the fact that a different degree of freedom existed which members of different ethnic communities possessed during the process of making economic and political decisions of importance for regulation of cross-border relations. This is precisely where the importance of harmonization of regulations on communitarian level in the area of cross-border cooperation of member states of EU came to fore - an issue that also belongs in the following considered group, i.e. political factors.

\subsection{Political factors}

Analogously with organization of economic activities comprising the base of economic system of a country, harmonization of different functions performed by border regions is an activity that makes an integral part of each political system of countries to which those regions belong. Those political activities result in setting priorities in terms of functions which a new created cross-border region has as a goal to perform.

Basic political factors determining those political activities include: (1) forming legal acts under which political parties are allowed to influence the functioning of border regions; (2) uniformity of legislation in political systems enabling creation of a cross-border region; and (3) signing multilateral agreements enabling a political party from one state to act undisturbed in several different member states of integration, that is, on the territory of the entire cross-border region. The first factor is the issue of national legislatures. The second factor, at the same time, is also the content of communitarian regulations of EU which are compulsory for all member states and, consequently, also for two states analysed in this part of the paper (Kelemen \& Pavone, 2018, p. 361). The third factor represents a way to ensure implementing appropriate policies simultaneously in more different signatory countries.

In this part of the paper, influence of political factors is observed on the example of Basque Region. Basque Country straddles northern parts of Spain and south-western parts of France. Political parties from Basque Country, whose policies are supported to a significant extent by the Spanish government, usually hold around $25 \%$ of seats in Basque Parliament. The majority of Parliament seats are usually held by Basque Nationalist Party. This party is the biggest political party, which won 28 out of 75 of Parliament seats in the 2016 elections in this Spanish region (Pallarés, 2016, p. 4). As opposed to Basque region in Spain, a separate Basque region is not formed officially in France. However, political activity of Basque Nationalist party is legitimately realized on that territory of the French part of Basque Country as well. This is precisely where the simultaneous influence of political factors of regional integration on both observed border regions can be seen. Tendency towards political and territorial independence of Basque Country represents the base of integrative factor which connects these two border regions.

The next example of establishing a cross-border region can be observed through Moravian region, which covers south-eastern parts of Czech Republic and exits on the border with Slovakia. Around 3.1 million of people live in this region, somewhat more than half of a million of whom officially declare themselves as Moravian national minority. The 
party of Moravia and Silesia (the Movement for Self-Governing Democracy - Association for Moravia and Silesia) was represented in Czech parliament as early as in 1992 with 14 Parliament seats and around 380.000 people voted for them then (Strmiska, 2000). However, unlike Basque Country, neither that party nor other parties from Moravian region, which are otherwise turned toward autonomy of this region, are currently represented in the Czech Parliament, although they are in the legal possibility to do that. Only $0.1 \%$ of population who officially declare themselves as Moravians currently live in Slovakia and they are concentrated in regions right next to the border with Czech Republic. Hence, it can be argued here that realization of the process of integration, which includes acting of political factors, requires continuous activity in relation to given political goals (Telle, 2017, p. 98).

Observed from the opposite direction and based on data used in the research which preceded the development of this paper, the following can also be inferred: independently from economic development between Spanish and French part of Basque Country, that is, between Czech and Slovakia, what happened was creation of certain cross-border forms of cooperation, as between border regions with the lowest, as well as with the highest level of income compared to national states in which they are situated. For these reasons, the dominant factors of integration in this case are historical and political influences rather than economic.

\section{Economic factors}

Customs union can be highlighted as one of the first forms of regional economic integration. Static effects influence the creation of customs union above all. Those are effects of creation and divergence of trade (Balassa, 1967, p. 5). If the concept of creation of trade yields better results than the concept of divergence of trade, economic integration will be considered successful. Unlike this form of integration, economic union implies forming of a common market, which assumes a dominant influence of dynamic effects of trade.

For a country or region to decide to access some form of economic integration it is necessary to previously conduct a procedure of cost-benefit analysis. This can be observed on the example of accessing to European Monetary Union (Grbić, 2005, p. 51). Considered dynamic economic factors act positively and represent benefits from accessing of a state to that integration. Decreasing of uncertainty, caused by accessing to European monetary union, contributes to better allocation of resources and to bigger specialization in production. It leads to accelerating economic growth and increase in investments. Achieved macroeconomic stability leads to increased stability of prices and domestic currency in monetary sphere. On the other hand, costs brought about by stable domestic currency are related to a loss of monetary sovereignty which is especially expressed in inability to resolve difficulties related to balance of payments using devaluations, as well as in a loss of issuance profits. 
Decision-making process on whether a country will access a monetary integration it could also be graphically shown, as seen in Figure 1. The ordinate marks benefits and costs resulting from integration of a country measured with their relation to GDP, whereas the abscissa expresses the degree of integration of the country with partners, measured by relation of trade integration to GDP. Line of benefits BB and line of costs CC cut in point $\mathrm{E}$, where benefits and costs are equal. Vertical line $\mathrm{HH}$ divides space in Figure 1 into two parts: left of line $\mathrm{HH}$ costs (C) are higher than benefits (B); right of line $\mathrm{HH}$ benefits are higher than costs $(\mathrm{B}>\mathrm{C})$. Based on this cost-benefit analysis, if the position of that country is on the right side in relation to line $\mathrm{HH}$, then it should be admitted to monetary union. Continuation in development of observed monetary integration, by action of dynamic factors, results in and increase in advantages of its existence. By that, the line of costs moves left $\left(\mathrm{C}^{*} \mathrm{C}^{*}\right)$, resulting in an increase in the areas of net benefits, which is manifested in moving a line $\mathrm{HH}$ to level $\mathrm{H}^{*} \mathrm{H}^{*}$. New balance is thus established in point $\mathrm{E}^{*}$.

Figure 1: Benefits and costs from monetary integration

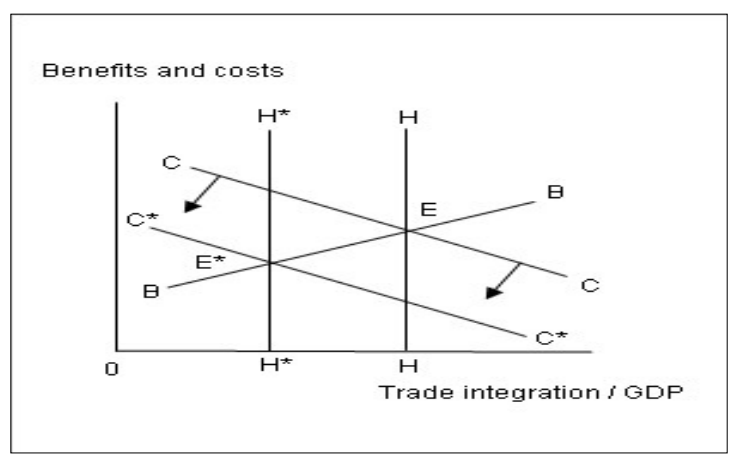

Source: Grbić, 2005, p. 52.

Analogous mechanism can also be applied to the analysis of potential cooperation of border regions with the aim of their integrations. This is particularly manifest in those member countries of the EU which are precisely also members of European monetary union, because membership in it enables implementation of uniform monetary policy on the territory of entire cross-border region. Observed from theoretical standpoint, this enables realization of better cooperation between border regions in other segments of economic policy as well.

The above results in equalization of a degree of economic development between these regions. This leads to a need for broader diversification of production in them, which levels precisely through already mentioned specialization in production, as one of basic economic factors of integration. Observed from the other side, if a bigger difference in a degree of development between cross-border regions exists, accelerated creation of spillover effects and impression effects in production and consumption are possible.

It can also be seen, on the observed example of Basque Country, that GDP per capita on average in Spanish part of Basque Country amounted to 34,000 euros in 2015. During 
the following year, 2016, it was 29.5\% higher than the level of GDP at the level of entire Spain and 17.7\% higher than EU average. During 2015, GDP per capita in French part of Basque Country on average amounted to 27,350 euros. In 2016, level of this GDP per capita remained unchanged. However, unlike Spain, where the level of this parameter on observed regional level is higher than its value on national level, GDP per capita in French part of Basque Country was $12 \%$ smaller than its value at the level of the whole France. Also, its value was 7\% lower than EU average in that year. Similar relation can be observed in 2018. During that year GDP per capita in regions comprising French part of Basque Country was 28,250 euros, which was $11.5 \%$ lower than its average level in France and $7.5 \%$ lower than its average in EU (Eurostat, 2020).

It is these differences in values of GDP per capita in Spanish and French part of Basque in relation to national averages and EU averages that leave space for more active implementation of observed economic factors. Its goal is to bring about mutual approximation of relative values of their GDP, because implementation of considered economic factors will also result in spillover of economic effects from a richer cross-border region to a poorer region.

Implementation of dynamic factors of integration also results in improved crossborder geographic and professional mobility of labour force. It also results in creation of conditions for increase in scale and diversification of agglomeration of production in certain cross-border regions parts of which comprise more different EU member states (Eraydin, 2016, p. 222). Observed like this, a model of economic growth, in which dynamic effects of trade are expressed in such a way that their usage results in long-term structural improvements in the economy, actually represents a model of economic development (Dragutinović et al, 2005, p. 255).

\section{Multifactorial influence on border regions in Europe}

In the interaction of non-economic factors with economic factors which are present in border regions, regional integrations are formed. To increase and improve number and diversification of those existing economic factors it is necessary to provide a legal environment for their integration, which is achieved through influence of political factors of integration (Brada \& Mendez, 1993, p. 187). Hence, political factors, as a form of noneconomic factors, are those that determine direction and dynamic of future integrative movements.

As an example of such interaction of observed factors, we can take existence of border regions of Alsace and Lorrain in France on the one side of the border and Ruhr and Saar area in Germany on the other. Economic policy in areas of energetics, especially in cooperation in production of coal and steel, can be highlighted as basic common factor of their integration. Other factors in relation to these regions are political relations and heterogeneous structure of population. Through history Alsace and Lorrain were many times an issue under dispute between states to which they belonged. Such policy of conflicts in relations between France and Germany, to which these regions alternately 
belonged, caused a need for their mutual cooperation through other factors of interregional cooperation. The majority of population of Alsace is of German origin. In periods of peace this fact brought about intense cooperation of this region with German population in the regions of Ruhr and Saar, which are nowadays within the state of Germany. Besides that, the economy of Alsace is industrialized to a significant extend. This had been contributed to by cross-border cooperation in production of raw materials and creation of technological located in these two German regions as well (Fraunhofer Institute for Systems and Innovation Research, 2000, p. 13). Observed from today's point of view, it is these positive influences of economic and demographic factors that overcome earlier negative effects of political factors between these border regions. As early as 1951, that cooperation was the aim of establishing the European Community for Coal and Steel, which is regarded as one of three major institutions on basis of which present-day EU emerged (Berger, 2012).

Such influence of considered factors also affects EU enlargement beneficially, which can also be seen on the example of Szeged and Subotica, in the context of accession of Serbia to the future membership in EU. Cooperation in the form of cross-border region would territorially include border regions of Szeged and Subotica. By that, common transport routes would be gathered as geographic factors on the one hand. As an example of this cooperation we can mention a project of a new railway route Szeged-Röszke-HorgošSubotica-Čikerija-Bácsalmás-Baja. This transversal could enable a connection between the two biggest harbours on the Adriatic and the Black Sea, as a part of railway between Rijeka in Croatia and Constanţa in Romania (Prime Minister's Office Hungary - Serbian European Integration Office, 2016). Also, this project would promote mutual relations of Hungarian and Serbian national minorities, communities of two most represented people, as demographic factors. At the same time, on the other hand, action of economic factors would be expressed through trade and financial cooperation, which would be conditioned precisely by geographic and demographic factors, as noneconomic. Projects through which this cooperation is conducted were applied for during the period from 2007 to 2013 within IPA programmes of cross-border cooperation between Serbia and Hungary. These projects were conducted on the territory of potential cross-border region between Hungary and Serbia, within the financial framework of Instrument for Pre-Accession Assistance of EU and the total number of them was 204. Among them, we can particularly highlight an infrastructural project of building a new integrated traffic border crossing between Hungary and Serbia: Ásotthalom - Bački Vinogradi, which was officially opened in 2013.

Cooperation in the form of cross-border region could also be established based on common policy in the area of energy industry (De Sousa, 2012). As an example of that, we could state the existence of Đerdap hydroelectric power plant in the basin of the River Danube on the border of Serbia and Romania It is on these examples that simultaneous common performance of noneconomic and economic factors in border regions can be seen.

Observed from the theoretical standpoint, this can be done in two ways. On microeconomic level, by directing allocation of companies in certain regions, in accordance with current political and economic programs. On macroeconomic level, by harmonizing economic cycles and political cycles for those time periods in which economic policy will accommodate to certain regions most, as it is shown in Figure 2. For example, if it is 
estimated for inhabitants of a region, potential voters in approaching regional elections, that their confidence will be achieved by reducing unemployment rather than by reducing inflation, appropriate economic policy should also be chosen in advance accordingly. Creators of macroeconomic policy will implement measures of expansive monetary and fiscal policy by which unemployment will be decreased, but on the other hand, it will lead to increase in inflation. As opposite to that, once elections have passed government will, with the aim of re-stabilization, once again initiate measures of inflation-controlling policy which will soon be reflected on increase in unemployment (Bajec \& Joksimović, 2004, p. 100). Such measures will be implemented until new elections, when government will once again try to acquire popularity among voters with full employment policy (Henley, 1988, p. 440).

Figure 2. Movement of inflation and unemployment through economic and political cycles

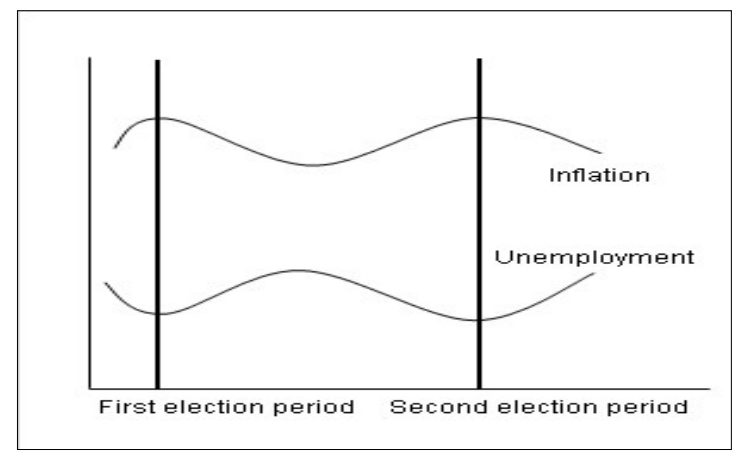

Source: Bajec \& Joksimović, 2004, p. 100.

However, implementation of a concept of policy on regional level in practice faces several basic problems. They can be defined in the following ways, carefully taking into consideration deficiencies of each of individually considered factors of integration.

First, geographic proximity of border regions is no longer a warranty for accelerating different forms of communications between them. Global connection between regions across Europe and the world through the most modern transport and telecommunication means is what diminished necessity for establishment of cross-border cooperation. Then, ethnic, linguistic and religious tolerance, particularly during the perennial implementation of the concept of multiculturalism, on the territory of the entire European Union, resulted in the fact that each form of migration and cooperation significantly outside of neighbouring and border regions encountered the approval of domicile population. However, the past several years have seen abandonment of concepts which justify and improve tendencies like this, which, on the other hand, once again opens possibility for strengthening cross-border cooperation of population of neighbouring states. Besides that, the aforementioned political activities before or after elections on regional levels are not often possible to implement in practice, because there exists pronouncedly strong interconnection of such policies with macroeconomic policies on national and 
communitarian level. Consequently, it is necessary to harmonize those regional policies constantly with the interests of wider administrative-territorial units, which leads to a series of problems of mutual mismatch of these interests. This can be seen, both in terms of content, and also at the time of preparation of such policies turned toward certain crossborder regions in relation to the level of entire state or the European Union. On the other hand, economic factors have already been conditioned by the process of globalization of the world economy for quite some time. Concepts of specialization in production and allocation of resources in cross-border regions are subject to ever-increasing displacement of production out of EU and with continuous drain of labour force, particularly highly educated, both in within the EU and outside its borders. For such state be changed, it is necessary to exert influence continuously and actively by means of different political and economic measures. Such activities should be aimed toward stopping further negative influences which have caused incomplete and partial implementation of considered factors of integration.

Accordingly, it can be concluded that for successful economic cooperation of border regions it is not enough to have only positive influence of economic factors on one side, but their simultaneous coaction with geographic, demographic and political factors, on the other. Based on that it can be asserted that basic hypothesis can be accepted as accurate. Noneconomic factors represent causal (geographic and demographic) factors as well as consequential (political) factors of each regional economic integration. Therefore, observed from the standpoint of qualitative analysis, their influence on economic factors has causalconsequential character. Such action of noneconomic factors results in a change in the form and a type of economic factors which then permanently shape a certain regional economic integration.

\section{Conclusion}

During the formation of European economic integration it was necessary to strengthen the influence of already existing economic factors in future member countries. Significance of simultaneous action of multiple factors came to the fore in the period after the Second World War precisely in regions which had, during history, represented areas with potentially conflicting interests. Importance of creation of preconditions in order to find compromise solutions and connect such areas through economic factors, was the basic goal of common European policy in that period. This mechanism of connecting of national states established early is, with appropriate modifications, also present today as one of the ways of maintaining and promoting integration in Europe.

From another point of view, independently of accession of new and strengthening the existing connections between already integrated member states, it is necessary to continue more direct cooperation between border regions in EU. Reason for that can be seen from the following: when problems arise on the level of connecting national states in EU, as it is currently the case with the process of exit of Great Britain from EU, maintaining and strengthening this integration is possible to search for solutions repeatedly on regional levels. The EU was also formed on those bases and they are always indicator of 
actual state and relations within it. For a longer time period already, the concept of Europe of the Regions, based on cross-border cooperation of interstate regions with tendency of creating of new regions, is suppressed from everyday political practice. However, the concept of European federalism, as currently dominant theoretical base of connecting territories in a composition of national states within Europe, is not producing expected results either.

The basic results of the research conducted in this paper can be classified into two groups. First, influences of individually applied factors can be pointed out:

- Spatial proximity and establishing of better cross-border infrastructural connections do improve a cooperation between observed regions and represent an influence of geographic factors on them.

- Demographic factors such as ethnic, educational and religious characteristics of a group of people living in a particular region also influences significantly possibilities for improving of cross-border cooperation. More similar characteristics contribute to easier communication on personal and business levels among people who live in border regions. Observing from another viewpoint, if significant differences in these characteristics of people who are residents of border regions exist, it can cause a decrease in geographic mobility of their population, particularly of labour force between these regions.

- As a consequence of such influence of geographic and demographic factors it is necessary to implement continuous harmonization of regulations in the area of communitarian law among regions involved in cross-border integration. This would facilitate decision making process as a form of political factor.

- Implementation of economic factors results in equalization of the degree of economic development between these regions, particularly through application of regional economic policies and increased cross-border geographic and professional mobility of labour force.

Second, in simultaneous implementation of noneconomic and economic factors there are also significant effects found during this analysis that can be pointed out here:

- With the acceleration of means of communications as geographic factors and with implications of concept of multiculturalism in Europe as political factors, the need for significant cross-border cooperation between its regions stopped in certain periods.

- Applied political factors in the form of macroeconomic policies on regional level cause strong interaction with macroeconomic policies on national and communitarian levels, which can be observed as additional negative consequence of simultaneous implementation of the analysed factors. 
- Globalization of the world economy made a strong impact on the observed noneconomic and economic factors and for this reason many cross-border regions in EU are not priority for investments.

As main implications of the research conducted in this paper, it can be stated that precisely because of these findings creators of new economic and political decisions could make better conclusions necessary for making policies and regulations concerning regional integrations more easily and better. Consequently, the following conclusion can be highlighted as the main contribution of this paper: individual influences of observed factors leads to various consequences affecting cooperation of border regions in comparison with their multifactorial influences caused by their simultaneous interaction. Observed all together, it can be asserted that noneconomic factors of integration, especially political, really contribute to better implementation of economic factors in the process of cooperation of border regions, which was, in fact, the content of basic hypothesis examined in this paper. Besides that, it can be concluded that not only do non-economic factors enable better utilization of existing economic factors of integration, but with their usage results in an increase in possibilities for implementation of new economic factors. This creates preconditions for new forms of cooperation of border regions, which is what Euroregions are, geographically and formally stretching beyond boundaries of national states, as further evidence of the supranational character of such regional economic integrations.

Based the above stated, it can be concluded that the concept of Europe of the Regions does not have to be only regarded as supplement, but also as appropriate complement, of the current concept of European federalism. The base for such approach like this to the concept of Europe of the Regions make border regions and their mutual relations manifest form of interaction of the considered factors of regional integration in Europe.

\section{References}

Bajec, J. \& Joksimović, Lj. (2004). Savremeni privredni sistemi. Beograd: Ekonomski fakultet.

Balassa, B. (1967). Trade creation and trade diversion in the economic common market. The Economic Journal, 77(305), 1-21. Doi: https://doi.org/10.2307/2229344

Berger, M. (2013). Motives for the foundation of the ECSC. Economics and Business Review, 13(3), 55-90.

Brada, J. C. \& Mendez, J. A. (1993). Political and economic factors in regional economic integration. Kyklos: International Review for Social Sciences, 46 (2), 183-201. Doi:

https://doi.org/10.1111/j.1467-6435.1993.tb02420.x

Collier, W. J. \& Vickerman, R. W. (2002). Cross-border activity in the Kent-Nord-Pas de Calais - Belgium Euroregion: Some comparative evidence on the location and recruitment decisions of internationally mobile firms. Paper for 42nd Congress of the European 
Regional Science Association, Germany, Dortmund. Retrieved on May 13 2020, from http://www-sre.wu-wien.ac.at/ersa/ersaconfs/ersa02/cd-rom/papers/082.pdf

De Sousa, L. (2012). Understanding European Cross-border Cooperation: A Framework for Analysis. Journal of European Integration, 35 (6), 669-687. Doi:

https://doi.org/10.1080/07036337.2012.711827

Dragutinović, D., Filipović, M. \& Cvetanović, S. (2005). Teorija privrednog rasta $i$ razvoja. Beograd: Centar za izdavačku delatnost Ekonomskog fakulteta u Beogradu.

Eraydin, A. (2016). The role of regional policies along with the external and endogenous factors in the resilience of regions. Cambridge Journal of Regions, Economy and Society, 9 (1), 217-234. Doi: https://doi.org/10.1093/cjres/rsv026

Euregio. (2020). INTERREG Germany-Netherlands. Euregio Rhein Waal, INTERREGPrograme management, Germany, Cleves. Retrieved on April 25, 2020, from http://www.euregio.org/interreg-v-deutschland-nederland/

Eurostat. (2020, March 5). GDP per capita in EU regions. Eurostat - newsrelease 38/2020. $\begin{array}{lllll}\text { Retreived on } & \text { September } & 17, & \text { from }\end{array}$ https://ec.europa.eu/eurostat/documents/2995521/10474907/1-05032020-AP-

EN.pdf/81807e19-e4c8-2e53-c98a-933f5bf30f58

Filip, P. \& Bogdan, S. M. (2016). The strategy concerning the development of the Danube Euroregion, between desire and pragmatism. Journal of Danubian Studies and Research, 6 (1), 28-41.

Fraunhofer Institute for Systems and Innovation Research. (2000). Socio-economic analysis of North-Rhine Westphalia. Working Papers Firms and Regions (No. R2/2000), Germany, Karlsruhe. Retrieved on September 19, 2020, from https://core.ac.uk/download/pdf/6625278.pdf

Grbić, V. (2005). Ekonomija Evropske Unije. Beograd: Megatrend univerzitet primenjenih nauka.

Henley, A. (1988). Political aspects of full employment: a reassessement of Kalecki. The Political Quarterly, 59 (4), 437-450. Doi: $\underline{\text { https://doi.org/10.1111/j.1467 }}$ 923X.1988.tb01227.X

Kelemen, D. R. \& Pavone, T. (2018). The political geography of legal integration visualizing institutional change in the European Union. World Politics, 70(3), 358-397. Doi: https://doi.org/10.1017/S0043887118000011

Knippenberg, H. (2004). The Maas-Rhine Euroregion: A laboratory for European integration? Geopolitics, 9(3), 608-626. Doi: https://doi.org/10.1080/1465004049047867

Marinov, E. (2015). Economic determinants of regional integration in developing countries. International Journal of Business and Management, 3(3), 22-39. Doi:

https://doi.org/10.20472/BM.2015.3.3.003 
Medeiros, E. (2019). Cross-border transports and cross-border mobility in EU border regions. Case studies on transport policy, 7(1), 1-12. Doi: https://doi.org/10.1016/i.cstp.2018.11.001

Ministry of Public Development and Public Works. (2020). INTERREG V-A RomaniaBulgaria Programme 2014-2020, Bulgaria, Sofia. Retrieved on May 07, 2020, from: http://www.mrrb.government.bg/en/infrastructure-and-programmes/programmes-forterritorial-cooperation-2014-2020/interreg-v-a-romania-bulgaria-programme-2014-2020/

OECD. (2014). Education at a glance 2014: OECD Indicators. Country note, The Secretary-General of the OECD, OECD Publishing. Doi: http://dx.doi.org/10.1787/eag 2014-en

Pallarés, F. (2016). 2016 Regional election in the Basque country: results and electoral behavior patterns. Institute of public law, Spain, Barcelona. Retrieved September 16, 2020, from http://idpbarcelona.net/docs/blog/euskadi.pdf

Prime Minister's Office Hungary - Republic of Serbia, Government, Serbian European Integration Office. (2016). IPA program prekogranične saradnje Mađarska-Srbija, Széchenyi Programiroda Nonprofit Kft 2015. Zajednički tehnički sekretarijat IPA Programa prekogranične saradnje Mađarska-Srbija, Mađarska, Budimpešta. Retrieved on May 17, 2020 from: http://www.interreg-ipa-husrb.com/srb/file/168/

Russo, A. M. (2012). Globalization and cross border cooperation in EU law: A transnational research agenda. Perspectives on Federalism, 4 (3), 1-25. Retrieved on March 28, 2020, from $\underline{\text { http://www.on- }}$ federalism.eu/attachments/004_Volume\%204\%20issue\%203\%202012.pdf

Strmiska, M. (2000). Rise and Fall of Moravian Regionalist Parties. Central European Political Studies Review, 2 (4). Retrieved on September 07, 2020, from: https://journals.muni.cz/cepsr/article/view/3835

Telle, S. (2017). Euroregions as soft spaces: between consolidation and transformation. European Spatial and Research policy, 24 (2), 93-110. Doi: https://doi.org/10.1515/esrp$\underline{2017-0011}$

Timmer, M. P., Miroudot, S., \& De Vries, G. J. (2019). Functional specialisation in trade. Journal of Economic Geography, 19(1), 1-30. Doi: https://doi.org/10.1093/jeg/lby056

Wroblewski, L. \& Kasperek, A. (2019). Euroregion as an entity stimulating the sustainable development of the cross-border market for cultural services in a city divided by a border. Sustanaibility, 11(8), 1-21. Doi: https://doi.org/10.3390/su11082232 